\title{
Asymmetric Synthesis of 5-Arylcyclohexenones by Rhodium(I)-Catalyzed Conjugate Arylation of Racemic 5-(Trimethylsilyl)cyclohexenone with Arylboronic Acid
} Qian Chen, Masami Kuriyama, Takahiro Soeta, Xinyu Hao, Ken-ichi Yamada, and Kiyoshi Tomioka* Graduate School of Pharmaceutical Sciences, Kyoto University, Yoshida, Sakyo-ku, Kyoto 606-8501, Japan

\section{Contents}

1. General S1

2. Preparation of racemic 1 S1

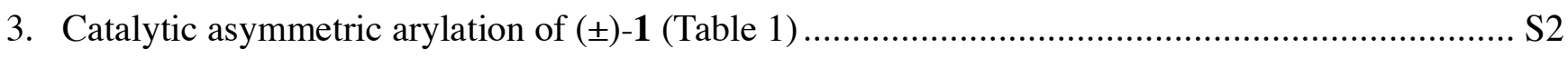

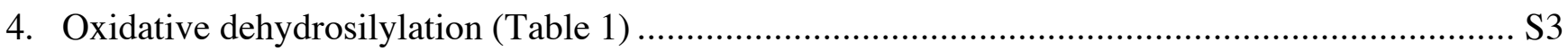

5. Correlation of the absolute configuration of $\mathbf{4}$ by hydrogenation to 5-arylcyclohexanones ........... S5

6. HPLC traces. S6-10

General. All melting points are not corrected. ${ }^{1} \mathrm{H}$ and ${ }^{13} \mathrm{C}$ NMR spectra were taken at 500 and $125 \mathrm{MHz}$, respectively, in $\mathrm{CDCl}_{3}$. Chemical shift values are expressed in ppm relative to internal tetramethylsilane. Abbreviations are as follows: s, singlet; d, doublet; t, triplet; q, quartet; m, multiplet; br, broad. IR spectra were expressed in $\mathrm{cm}^{-1}$.

Preparation of racemic 5-(trimethylsilyl)cyclohex-2-enone (1). Racemic 1 (CAS 56917-71-6: Asaoka, M.; Shima, K.; Takei, H. Tetrahedron Lett. 1987, 28, 5669-5672.) was prepared according to the reported procedures. 


\section{Catalytic asymmetric conjugate phenylation of 5-(trimethylsilyl)cyclohex-2-enone (1) using} $\left[\mathbf{R h C l}\left(\mathbf{C}_{2} \mathbf{H}_{4}\right)_{2}\right]_{2}$ (Table 1, entry 1): a flask charged with $\left[\mathrm{RhCl}\left(\mathrm{C}_{2} \mathrm{H}_{4}\right)\right]_{2}(5.8 \mathrm{mg}, 0.015 \mathrm{mmol})$, ligand $\mathbf{5}$ (11.6 mg, $0.033 \mathrm{mmol})$, and phenylboronic acid $(610 \mathrm{mg}, 5.0 \mathrm{mmol}$ ) was flushed with argon. 1,4Dioxane $(2.5 \mathrm{~mL})$ and $0.25 \mathrm{~mL}$ of $4 \mathrm{M}$ aq. $\mathrm{KOH}(1.0 \mathrm{mmol})$ were successively added. The mixture was stirred at $\mathrm{rt}$ for $1 \mathrm{~h}$ and then 5-trimethylsilylcyclohex-2-enone (1) (168 mg, $1.0 \mathrm{mmol}$ ) was added. The resulting mixture was stirred at $60{ }^{\circ} \mathrm{C}$ for $3 \mathrm{~h}$. After dilution with AcOEt $(40 \mathrm{~mL})$, the mixture was washed with $10 \% \mathrm{NaOH}(10 \mathrm{~mL})$ and brine $(20 \mathrm{~mL})$, and then dried over $\mathrm{Na}_{2} \mathrm{SO}_{4}$. Concentration and silica gel column chromatography (hexane/AcOEt $=30 / 1$ ) gave a 59:41 mixture of trans-2a and cisent-3a (224 mg, 91\%) as a colorless oil.

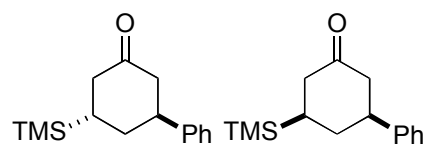

$(3 S, 5 S)$ - and (3S,5R)-3-Phenyl-5-trimethylsilylcyclohexanone (trans-2a

and cis-ent-3a): 2a:ent-3a = 59:41 (determined by the integration area of ${ }^{1} \mathrm{H}$ NMR signals at 3.52-3.56 ppm of the trans-2a and 3.01-3.07 ppm of the cis-3a). 76\% ee for 2a and 98\% ee for ent-3a (Daicel Chiralcel OD-H, hexane/2-propanol = 50/1, $254 \mathrm{~nm}, 0.5 \mathrm{~mL} / \mathrm{min}$, trans-2a: 14.7 and 15.7 min for major and minor; cis-ent-3a: 17.0 and 21.1 min for major and minor).

With $(S)$-BINAP 6 and $\mathrm{Rh}($ acac $)\left(\mathrm{C}_{2} \mathrm{H}_{4}\right)_{2}$ the asymmetric reaction was carried out as shown in text.<smiles>COc1cccc(C2CC(=O)C[C@H](C)C2)c1</smiles><smiles>COc1cccc(C2CC(=O)CC(S(C)(=O)=O)C2)c1</smiles>

$(3 S, 5 S)-\quad$ and (3S,5R)-3-(3-Methoxyphenyl)-5trimethylsilylcyclohexanone (trans-2b and cis-ent-3b) (Table 1, entry 4): a colorless oil purified by silica gel chromatography (hexane/ $\mathrm{Et}_{2} \mathrm{O}=25 / 1$ ). $\mathbf{2 b}$ :ent $\mathbf{3} \mathbf{3 b}=61: 39$ (determined by the integration area of ${ }^{1} \mathrm{H}$ NMR signals at 3.48-3.53 ppm of the trans-2b and 3.00-3.04 ppm of the cis-ent-3c). 83\% ee for 2b and 99\% ee for ent-3b (Daicel Chiralpak AD-H, hexane/2-propanol = 100/1, $254 \mathrm{~nm}, 0.5 \mathrm{~mL} / \mathrm{min}$, trans-2b: 19.5 and $22.4 \mathrm{~min}$ for major and minor; cis-ent-3b: 24.9 and $24.1 \mathrm{~min}$ for major and minor).<smiles>Cc1cccc(ONC2CC(=O)CC(c3cccc(C)c3)C2)c1</smiles>

$(3 S, 5 S)-$

and (3S,5R)-3-(3-Chlorophenyl)-5trimethylsilylcyclohexanone (trans-2c and cis-ent-3c) (Table 1, entry 6): a colorless oil purified by silica gel chromatography (hexane/acetone $=50 / 1$ ). 2c:ent-3c $=63: 37$ (determined by the integration area of ${ }^{1} \mathrm{H}$ NMR signals at 3.48-3.52 ppm of the trans-2c and 2.98-3.04 ppm of the cis-ent-3c). Ee \% 
was not determined because of poor separation by HPLC (Daicel Chiralpak AD-H, hexane/2-propanol $=50 / 1,254 \mathrm{~nm}, 0.5 \mathrm{~mL} / \mathrm{min})$. Directly used in the next elimination to $\mathbf{4 c}$ with $90 \%$ ee.
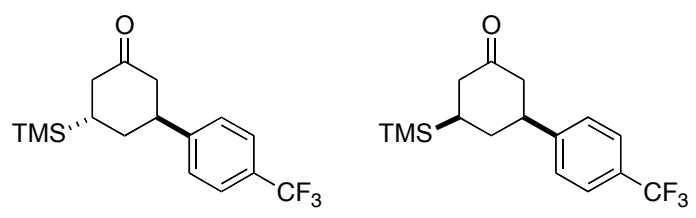

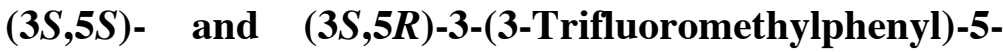

trimethylsilylcyclohexanone (trans-2d and cis-ent-3d) (Table 1, entry 8): a colorless oil purified by silica gel chromatography (hexane/acetone $=50 / 1$ ). $\mathbf{2 d}$ :ent-3d $=63: 37$ (determined by the integration area of ${ }^{1} \mathrm{H}$ NMR signals at 3.60-3.64 ppm of the trans-2d and 3.07-3.13 ppm of the cis-ent-3d). 88\% ee for 2d and 99\% ee for ent-3d (Daicel Chiralpak AD-H, hexane/2-propanol = 100/1, $254 \mathrm{~nm}, 0.5$ $\mathrm{mL} / \mathrm{min}$, trans-2d: 25.9 and 31.5 min for major and minor; cis-ent-3d: 35.2 and 28.7 min for major and minor).
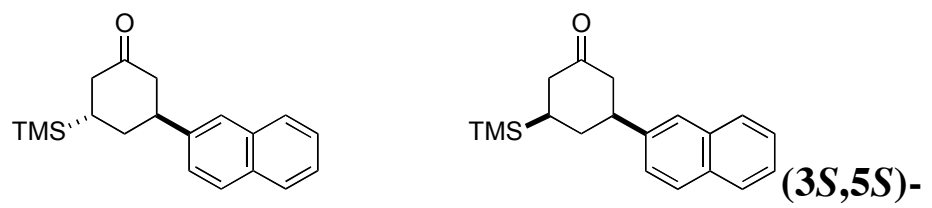

and (3S,5R)-3-(Naphth-2-yl)-5-

trimethylsilylcyclohexanone (trans-2e and cis-ent-3e) (Table 1, entry 10): a white solid purified by silica gel chromatography $\left(\mathrm{C}_{6} \mathrm{H}_{6} / \mathrm{AcOEt}=50: 1\right)$. 2e:ent-3e $=51: 49$ (determined by the integration area of ${ }^{1} \mathrm{H}$ NMR signals at 3.61-3.65 ppm of the trans-2e and 3.08-3.13 ppm of the cis-ent-3e). 83\% ee for 2e and 99\% ee for ent-3e (Daicel Chiralcel OD-H, hexane/2-propanol = 50/1, $254 \mathrm{~nm}, 0.5 \mathrm{~mL} / \mathrm{min}$, trans-2e: 19.1 and $23.1 \mathrm{~min}$ for major and minor; cis-ent-3e: 27.2 and 38.7 min for major and minor).<smiles>O=C1C=CC[C@H](O)C1</smiles>

Oxidative dehydrosilylation. (S)-5-Phenylcyclohex-2-enone $(S)-4 a$ (Table 2, entry 1): a mixture of $2 \mathbf{a}$ and ent-3a $(123 \mathrm{mg}, 0.50 \mathrm{mmol})$ and anhydrous $\mathrm{CuCl}_{2}(201 \mathrm{mg}, 1.5 \mathrm{mmol})$ in DMF (2 $\mathrm{mL})$ was stirred at $60^{\circ} \mathrm{C}$ for $3 \mathrm{~h}$. The mixture was diluted with water $(10 \mathrm{~mL})$ and filtered through short pad of celite. The filtrate was extracted with ether and the extract was dried over $\mathrm{Na}_{2} \mathrm{SO}_{4}$. Concentration and silica gel column chromatography (hexane/AcOEt = 15/1) gave $(S)$-5phenylcyclohex-2-enone $(S)-4 a(63 \mathrm{mg}, 73 \%)$ with $83 \%$ ee as a colorless oil of $[\alpha]_{\mathrm{D}}^{20}+31.4(c 1.2$, $\left.\mathrm{CHCl}_{3}\right)\left([\alpha]_{\mathrm{D}}^{23}-46.4\right.$ (c 5.0, $\left.\mathrm{CHCl}_{3}\right)$ for (R)-4a: Asaok, M.; Shima, K.; Fujii, N.; Takei, H. Tetrahedron 1988, 44, 4757-4766). 83\% ee (Daicel Chiralcel OJ-H, hexane/2-propanol = 7/1, $254 \mathrm{~nm}, 0.5 \mathrm{~mL} / \mathrm{min}$, 32.9 and 28.6 min for major and minor). 


\section{Supporting Information}

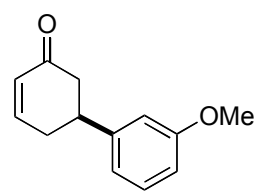

(S)-5-(3-Methoxyphenyl)cyclohex-2-enone (4b) (Table 1, entry 4): a colorless oil purified by silica gel chromatography (hexane/acetone $=10 / 1)$. $[\alpha]^{20}{ }_{\mathrm{D}}+24.1\left(c 1.12, \mathrm{CHCl}_{3}\right) .93 \%$ ee (Daicel Chiralcel OD-H, hexane/2-propanol =5/1, $254 \mathrm{~nm}, 0.5 \mathrm{~mL} / \mathrm{min}, 36.0$ and $38.9 \mathrm{~min}$ for major and minor). ${ }^{1} \mathrm{H}$ NMR: $2.54-2.57(\mathrm{~m}, 1 \mathrm{H}), 2.61-2.73(\mathrm{~m}, 3 \mathrm{H}), 3.30-3.36(\mathrm{~m}, 1 \mathrm{H}), 3.81(\mathrm{~s}, 3 \mathrm{H}), 6.12(\mathrm{~d}$, $J=10 \mathrm{~Hz}, 1 \mathrm{H}), 6.79-6.85$ (m, 3H), 7.04-7.07 (m, 1H), 7.26-7.29 (m, 1H). ${ }^{13} \mathrm{C}$ NMR: 33.6, 40.9, 44.8, 55.2, 111.9, 112.9, 119.0, 129.8, 144.9, 149.5, 159.9, 199.2. IR (neat): 1678. EIMS m/z: $202\left(\mathrm{M}^{+}\right)$. HRMS-EI: [M] $]^{+}$Calcd for $\mathrm{C}_{13} \mathrm{H}_{14} \mathrm{O}_{2}, 202.0994$; found, 202.0987.

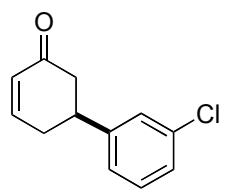

(S)-5-(3-Chlorophenyl)cyclohex-2-enone $(S)-4 c$ (Table 1, entry 6): a colorless oil purified by silica gel chromatography (hexane/acetone=40/1). $[\alpha]_{\mathrm{D}}^{20}+32.2$ (c 1.23, $\mathrm{CHCl}_{3}$ ). $90 \%$ ee (Daicel Chiralpak AS-H, hexane/2-propanol = 5/1, $254 \mathrm{~nm}, 0.5 \mathrm{~mL} / \mathrm{min}, 27.3$ and 30.0 min for major and minor). ${ }^{1} \mathrm{H}$ NMR: 2.49-2.56 (m, 1H), 2.59-2.72 (m, 3H), 3.30-3.37 (m, 1H), 6.14 (d, $J=9.8 \mathrm{~Hz}$, 1H), 7.03-7.06 (m, 1H), 7.13 (d, $J=7.4 \mathrm{~Hz}, 1 \mathrm{H}), 7.24-7.30(\mathrm{~m}, 3 \mathrm{H}) .{ }^{13} \mathrm{C} \mathrm{NMR}: 33.3,40.5,44.5,124.9$, 127.0, 127.2, 129.9, 130.1, 134.6, 145.2, 149.1, 198.6. IR (neat): 1678. EIMS m/z: $206\left(\mathrm{M}^{+}\right)$. HRMS-EI: [M] $]^{+}$Calcd for $\mathrm{C}_{12} \mathrm{H}_{11} \mathrm{ClO}, 206.0498$; found, 206.0503.

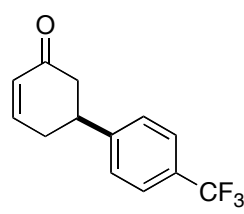

$(S)-5-(4-(T r i f l u o r o m e t h y l) p h e n y l) c y c l o h e x-2-e n o n e ~(S)-4 d$ (Table 1, entry 8): a colorless oil purified by silica gel chromatography (hexane/ $\left.\mathrm{Et}_{2} \mathrm{O}=10 / 1\right)$. $[\alpha]^{20}{ }_{\mathrm{D}}+34.5\left(c 1.02, \mathrm{CHCl}_{3}\right)$. 93\% ee (Daicel Chiralpak AD, hexane/2-propanol = 50/1, $254 \mathrm{~nm}, 0.5 \mathrm{~mL} / \mathrm{min}, 29.2$ and $27.4 \mathrm{~min}$ for major and minor). ${ }^{1} \mathrm{H}$ NMR: 2.55-2.59 (m, 1H), 2.64-2.75 (m, 3H), 3.40-3.47 (m, 1H), $6.15(\mathrm{~d}, J=10$ $\mathrm{Hz}, 1 \mathrm{H}), 7.04-7.08(\mathrm{~m}, 1 \mathrm{H}), 7.37(\mathrm{~d}, J=8.2 \mathrm{~Hz}, 2 \mathrm{H}), 7.62(\mathrm{~d}, J=8.2 \mathrm{~Hz}, 2 \mathrm{H}) .{ }^{13} \mathrm{C}$ NMR: 33.2, 40.6, 44.3, 124.1 (q, $J=270.7 \mathrm{~Hz}), 125.8,127.1,129.3$ (q, $J=32.9 \mathrm{~Hz}), 129.9,147.1,148.9$, 198.3. IR(neat): 1682. EIMS m/z: $240\left(\mathrm{M}^{+}\right)$. HRMS-EI: [M] $]^{+}$Calcd for $\mathrm{C}_{13} \mathrm{H}_{11} \mathrm{~F}_{3} \mathrm{O}, 240.0762$; found, 240.0759 .

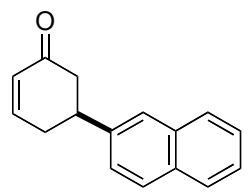

$(S)-5-(N a p h t h-2-y l) c y c l o h e x-2-e n o n e ~(S)-4 e$ (Table 1, entry 10): a white solid of mp 95-98 ${ }^{\circ} \mathrm{C} .[\alpha]_{\mathrm{D}}^{25}+41\left(c\right.$ 1.02, $\left.\mathrm{CHCl}_{3}\right) .90 \%$ ee (Daicel Chiralcel OD-H, hexane/2-propanol = 2/1, 254 $\mathrm{nm}, 0.5 \mathrm{~mL} / \mathrm{min}, 20.5$ and $25.3 \mathrm{~min}$ for major and minor). ${ }^{1} \mathrm{H}$ NMR: $2.60-2.82(\mathrm{~m}, 4 \mathrm{H}), 3.46-3.55$ (m, 
$1 \mathrm{H}), 6.16(\mathrm{~d}, J=10 \mathrm{~Hz}, 1 \mathrm{H}), 7.05-7.08(\mathrm{~m}, 1 \mathrm{H}), 7.37(\mathrm{~d}, J=8.6 \mathrm{~Hz}, 1 \mathrm{H}), 7.45-7.50(\mathrm{~m}, 2 \mathrm{H}), 7.66(\mathrm{~s}$, 1H), 7.80-7.84 (m, 3H). ${ }^{13} \mathrm{C}$ NMR: 33.5, 41.0, 44.8, 125.0, 125.2, 125.8, 126.3, 127.7, 127.8, 128.5, 129.8, 132.5, 133.5, 140.6, 149.4, 199.1. IR (nujol): 1662. EIMS m/z: $222\left(\mathrm{M}^{+}\right)$. Anal. Calcd for $\mathrm{C}_{16} \mathrm{H}_{14} \mathrm{O}: \mathrm{C}, 86.45 ; \mathrm{H}, 6.35$. Found: C, 86.25; H, 6.49.

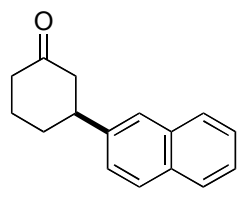

Correlation of the absolute configuration of 5-arylcyclohexenones 4 with that reported by hydrogenation to 5-arylcyclohexanones. (S)-3-(Naphth-2-yl)cyclohexanone: A mixture of $(S)-4 e$ with $94 \%$ ee $(50 \mathrm{mg}, 0.23 \mathrm{mmol}$, not listed in Table) and 10\% Pd/C (60 mg, 0.056 $\mathrm{mmol})$ in AcOEt $(8 \mathrm{~mL})$ was stirred under $\mathrm{H}_{2}$ atmosphere for $1.5 \mathrm{~h}$. Filtration, concentration and silica gel column chromatography (hexane/acetone $=10 / 1)$ gave $(S)-3$-(naphth-2-yl)cyclohexanone $(50 \mathrm{mg}$, $99 \%)$ as a white solid of mp $110-112^{\circ} \mathrm{C}$. $[\alpha]_{\mathrm{D}}^{20}-7.8\left(c\right.$ 1.04, $\left.\mathrm{CHCl}_{3}\right)\left([\alpha]^{20}{ }_{\mathrm{D}}-8.3\left(c 0.89, \mathrm{CHCl}_{3}\right)\right.$ for (S)-compound with 99\% ee: Takaya, Y.; Ogasawara, M.; Hayashi, T. Tetrahedron Lett. 1999, 40, 6957-6961). 94\% ee (Daicel Chiralcel OD-H, hexane/2-propanol = 50/1, $254 \mathrm{~nm}, 0.5 \mathrm{~mL} / \mathrm{min}, 44.4$ and 51.6 min for major and minor).

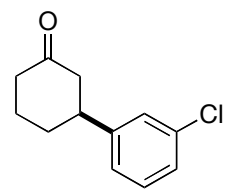

(S)-3-(3-Chlorophenyl)cyclohexanone: Hydrogenation of $\mathbf{4 c}$ with $78 \%$ ee (Table 1 , entry 5) and silica gel column chromatography (hexane/acetone =15/1) gave $(S)-3-(3-$ chlorophenyl)cyclohexanone as a colorless oil in $98 \%$ yield. $[\alpha]^{20}{ }_{\mathrm{D}}-11.1\left(c 1.04, \mathrm{CHCl}_{3}\right)\left([\alpha]^{20}{ }_{\mathrm{D}}-9.5\right.$ ( $c 1.13, \mathrm{CHCl}_{3}$ ) for (S)-compound with 96\% ee: Takaya, Y.; Ogasawara, M.; Hayashi, T. J. Am. Chem. Soc. 1998, 120, 5579-5580). 80\% ee (Daicel Chiralpak AD, hexane/2-propanol = 50/1, $254 \mathrm{~nm}, 0.5$ $\mathrm{mL} / \mathrm{min}, 18.1$ and $21.0 \mathrm{~min}$ for major and minor).

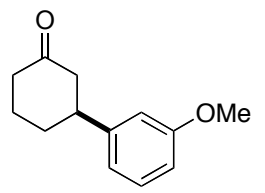

(S)-3-(3-Methoxyphenyl)cyclohexanone: Hydrogenation of $\mathbf{4 b}$ with $84 \%$ ee (Table 1 , entry 3) and silica gel column chromatography (hexane/acetone = 20/1) gave (S)-3-(3methoxyphenyl)cyclohexanone as a colorless oil. $[\alpha]^{20}{ }_{\mathrm{D}}-12.4\left(c 0.99, \mathrm{CHCl}_{3}\right)\left([\alpha]_{\mathrm{D}}^{20}-13.0(c 0.91\right.$, $\mathrm{CHCl}_{3}$ ) for $(S)$-compound with $96 \%$ ee: Takaya, Y.; Ogasawara, M.; Hayashi, T. J. Am. Chem. Soc. 1998, 120, 5579-5580). 84\% ee (Daicel Chiralcel OD-H, hexane/2-propanol = 50/1, $254 \mathrm{~nm}, 1 \mathrm{~mL} / \mathrm{min}$, 27.3 and 31.0 min for major and minor). 


\section{Supporting Information}<smiles>O=C1CCCC(c2ccc(C(F)(F)F)cc2)C1</smiles>

(S)-3-(4-(Trifluoromethyl)phenyl)cyclohexanone: Hydrogenation of $4 \mathbf{d}$ with $80 \%$ ee

(Table 1, entry 7) and silica gel column chromatography (hexane/acetone $=15 / 1$ ) gave a white solid of $\operatorname{mp} 75-77^{\circ} \mathrm{C} .[\alpha]^{20}{ }_{\mathrm{D}}-8.0\left(c 0.99, \mathrm{CHCl}_{3}\right)\left([\alpha]^{20}{ }_{\mathrm{D}}-11.0\left(c 0.97, \mathrm{CHCl}_{3}\right)\right.$ for $(S)$-compound with $99 \%$ ee: Takaya, Y.; Ogasawara, M.; Hayashi, T. J. Am. Chem. Soc. 1998, 120, 5579-5580). 80\% ee (Daicel Chiralcel OD-H, hexane/2-propanol = 50/1, $254 \mathrm{~nm}, 0.5 \mathrm{~mL} / \mathrm{min}, 25.3$ and 23.7 min for major and minor).

General: Daicel Chiralpak AD or AS-H, or Chiralcel OJ-H or OD-H were used with detection at $254 \mathrm{~nm}$.

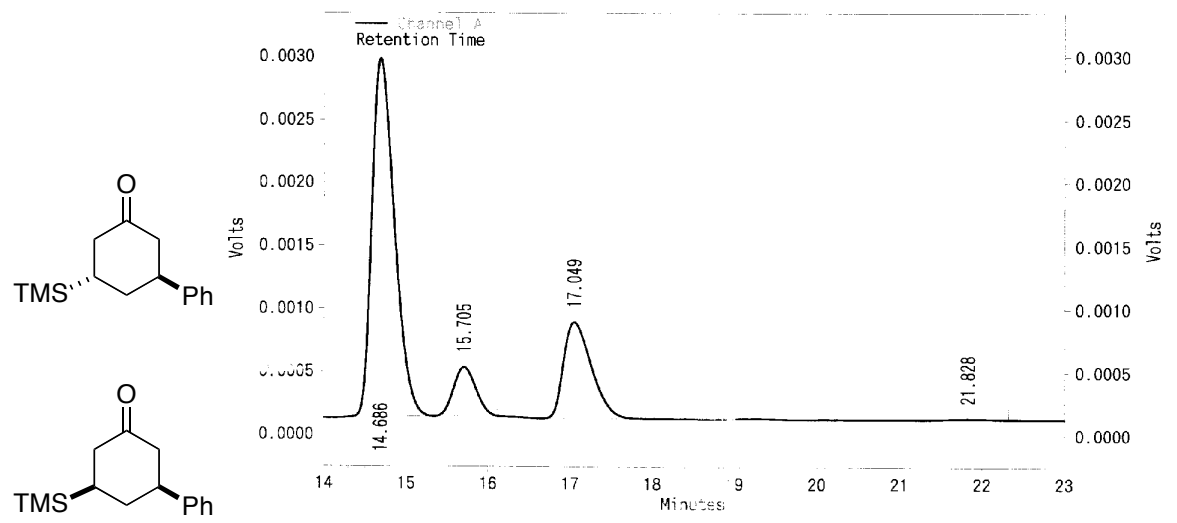

trans-2a: 76\% ee; cis-ent-3a: $98 \%$ ee $(\mathrm{OD}-\mathrm{H}$, hexane/2-propanol $=50 / 1,0.5 \mathrm{~mL} / \mathrm{min}$, trans: 14.7 and $15.7 \mathrm{~min}$ for major and minor; cis: 17.0 and 21.1 min for major and minor).

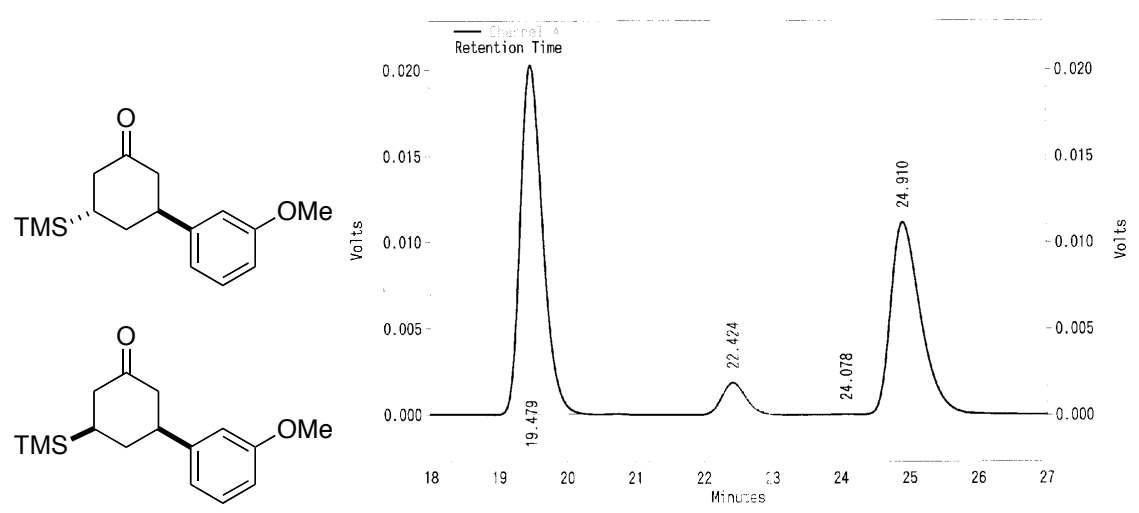

trans-2b: $83 \%$ ee; cis-ent-3b: 99.9\% ee (AD-H, hexane/2-propanol = 100/1, $0.5 \mathrm{~mL} / \mathrm{min}$, trans: 19.5 and $22.4 \mathrm{~min}$ for major and minor; cis: 24.9 and 24.1 min for major and minor). 


\section{Supporting Information}

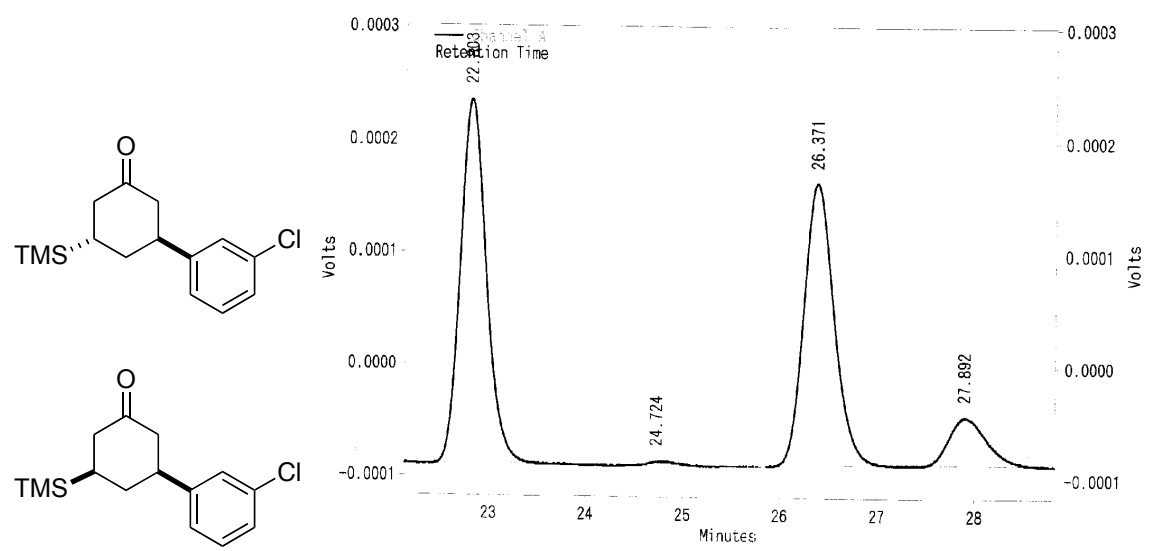

trans-2c: 70\% ee; cis-ent-3c: $97 \%$ ee $(\mathrm{AD}-\mathrm{H}$, hexane/2-propanol $=50 / 1,0.5 \mathrm{~mL} / \mathrm{min}$, trans: 22.8 and $27.9 \mathrm{~min}$ for major and minor; cis: 26.4 and 24.7 min for major and minor).

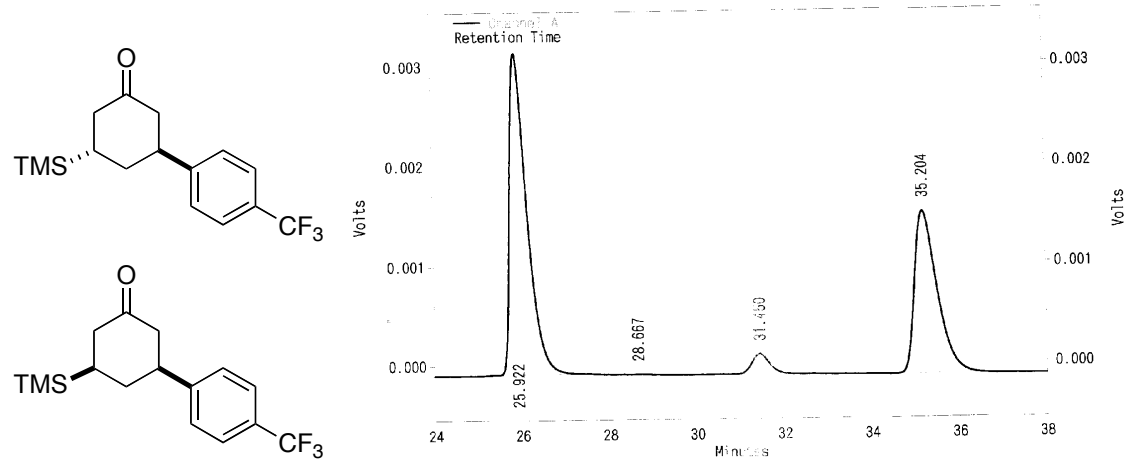

trans-2d: 88\% ee; cis-ent-3d: $99 \%$ ee $(\mathrm{AD}-\mathrm{H}$, hexane/2-propanol $=100 / 1,0.5 \mathrm{~mL} / \mathrm{min}$, trans: 25.9 and $31.5 \mathrm{~min}$ for major and minor; cis: 35.2 and 28.7 min for major and minor).

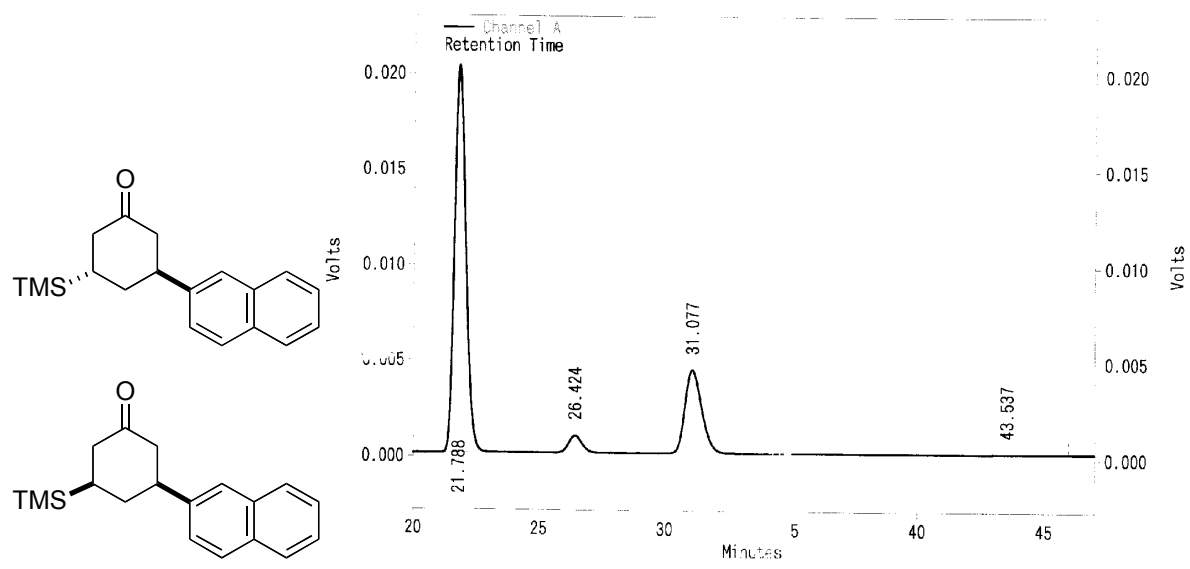

trans-2e: $90 \%$ ee; cis-ent-3e: $99 \%$ ee $(\mathrm{OD}-\mathrm{H}$, hexane/2-propanol $=50 / 1,0.5 \mathrm{~mL} / \mathrm{min}$, trans: 21.8 and $26.4 \mathrm{~min}$ for major and minor; cis: 31.1 and 43.5 min for major and minor). 


\section{Supporting Information}

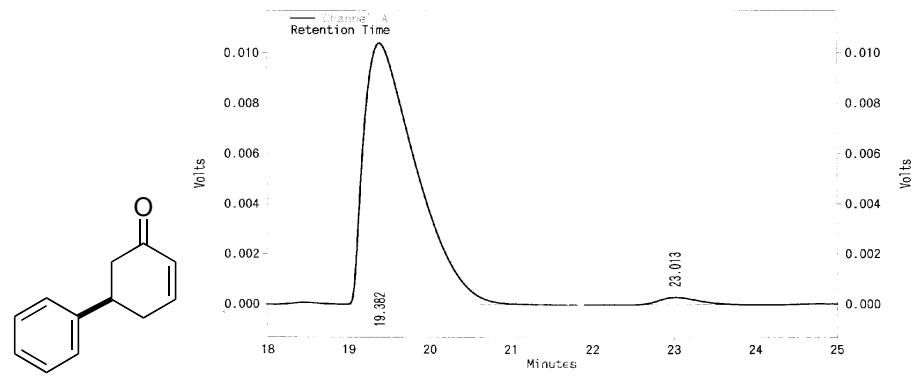

$(R)$-4a: $96 \%$ ee $(\mathrm{OJ}-\mathrm{H}$, hexane/2-propanol = 7/1, $0.5 \mathrm{~mL} / \mathrm{min}, 19.4$ and $23.0 \mathrm{~min}$ for major and minor).

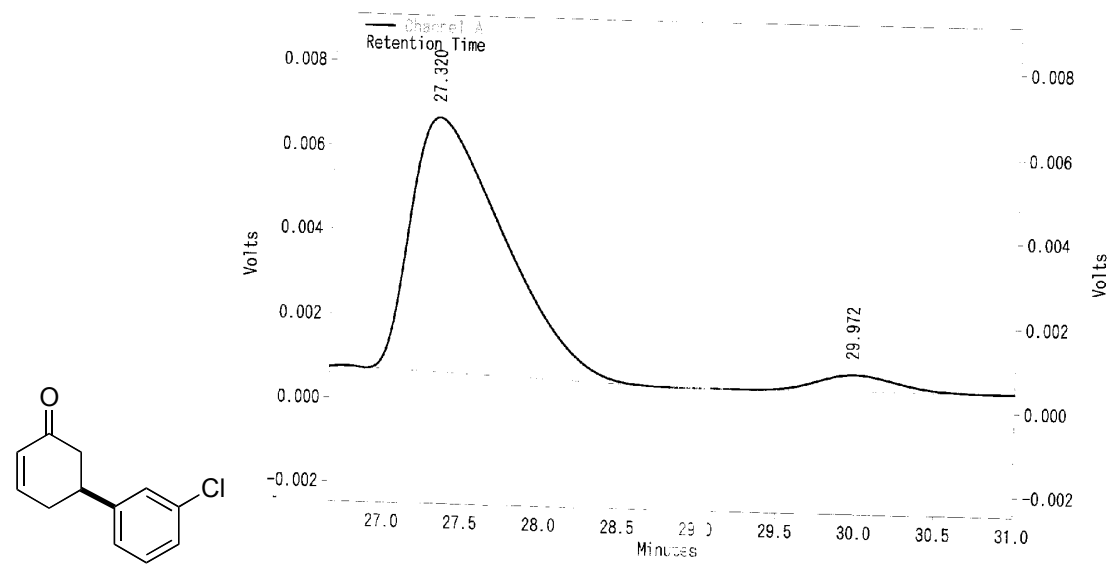

4c: $90 \%$ ee (AS-H, hexane/2-propanol $=5 / 1,0.5 \mathrm{~mL} / \mathrm{min}, 27.3$ and $30.0 \mathrm{~min}$ for major and minor).

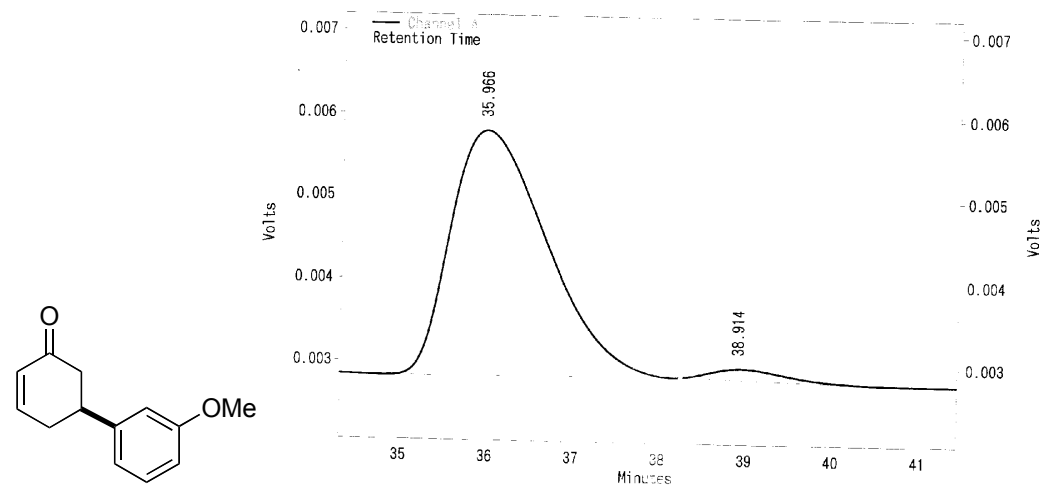

4b: $93 \%$ ee (OD-H, hexane/2-propanol = 5/1, $0.5 \mathrm{~mL} / \mathrm{min}, 36.0$ and $38.9 \mathrm{~min}$ for major and minor). 


\section{Supporting Information}

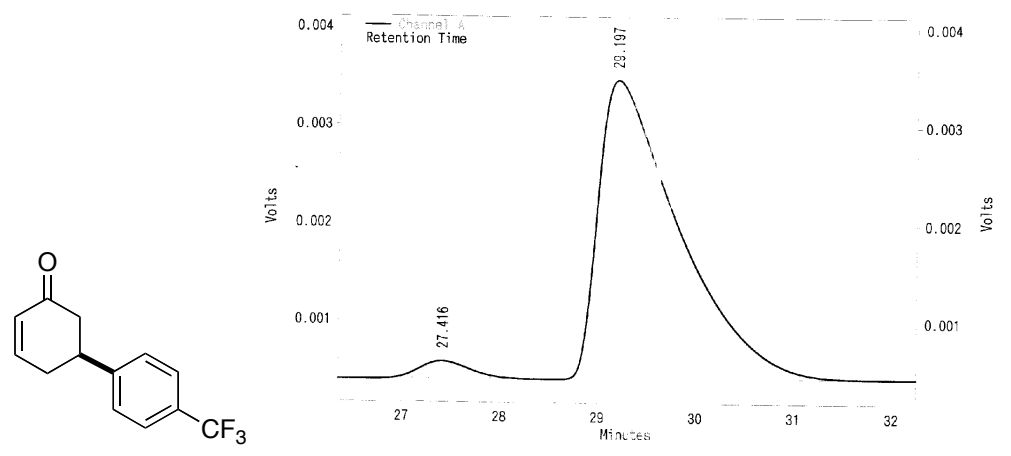

4d: $93 \%$ ee $(\mathrm{AD}$, hexane/2-propanol = 50/1, $0.5 \mathrm{~mL} / \mathrm{min}, 29.2$ and $27.4 \mathrm{~min}$ for major and minor).

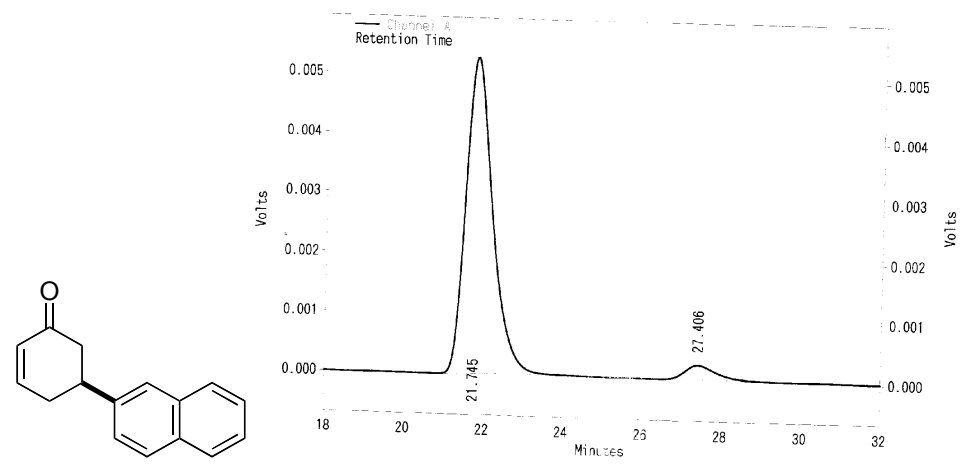

4e: $90 \%$ ee (OD-H, hexane/2-propanol = 3/1, $254 \mathrm{~nm}, 0.5 \mathrm{~mL} / \mathrm{min}, 21.7$ and $27.4 \mathrm{~min}$ for major and minor).

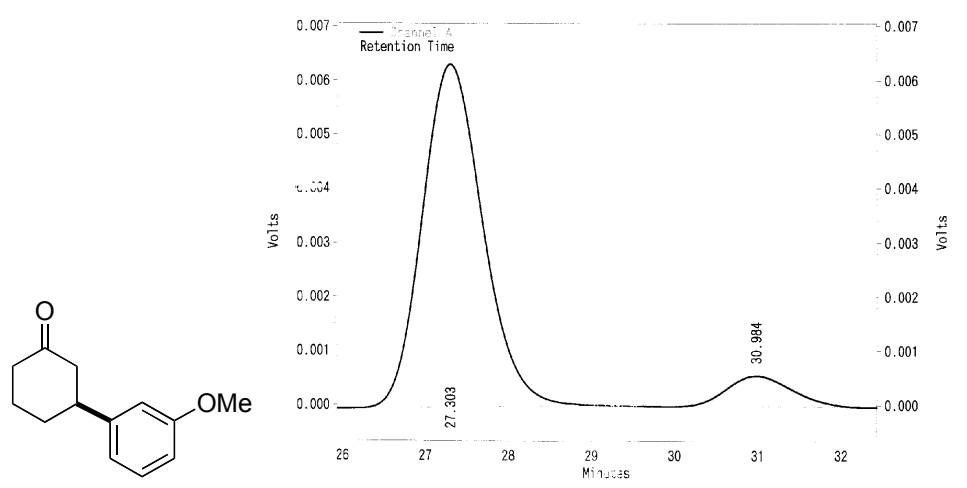

$84 \%$ ee $(\mathrm{OD}-\mathrm{H}$, hexane/2-propanol = 50/1, $1 \mathrm{~mL} / \mathrm{min}, 27.3$ and $31.0 \mathrm{~min}$ for major and minor). 


\section{Supporting Information}

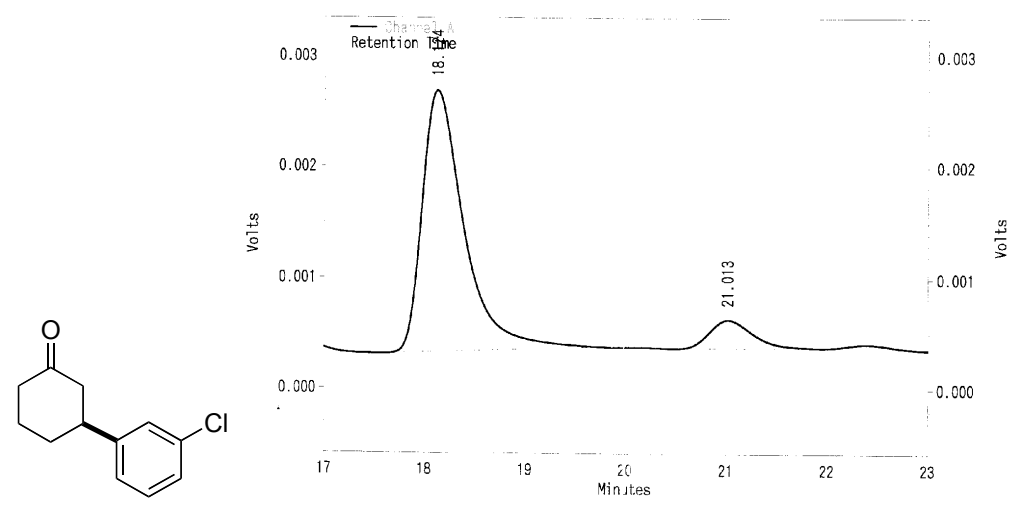

$80 \%$ ee $(\mathrm{AD}$, hexane $/ 2$-propanol $=50 / 1,0.5 \mathrm{~mL} / \mathrm{min}, 18.1$ and $21.0 \mathrm{~min}$ for major and minor $)$.

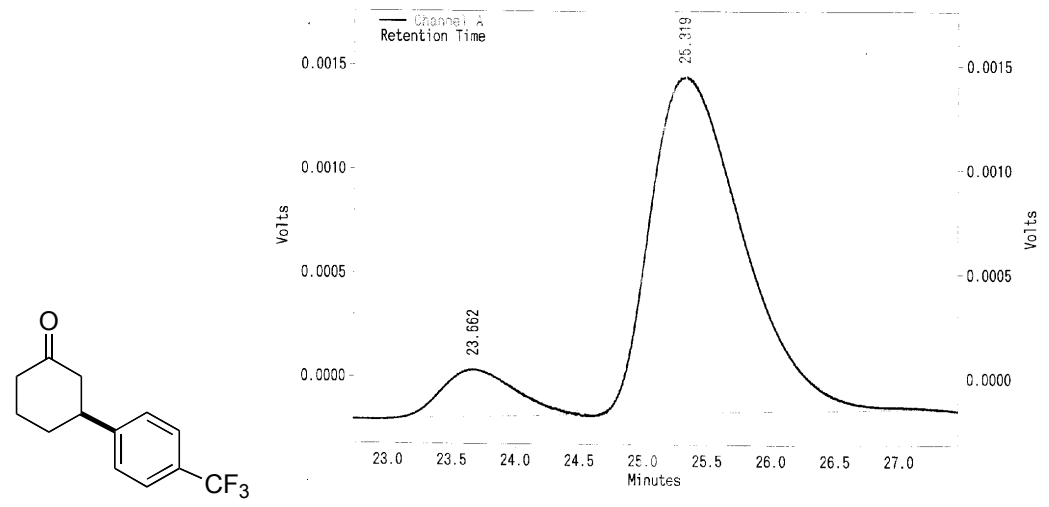

$80 \%$ ee $(\mathrm{OD}-\mathrm{H}$, hexane $/ 2$-propanol $=50 / 1,0.5 \mathrm{~mL} / \mathrm{min}, 25.3$ and $23.7 \mathrm{~min}$ for major and minor).

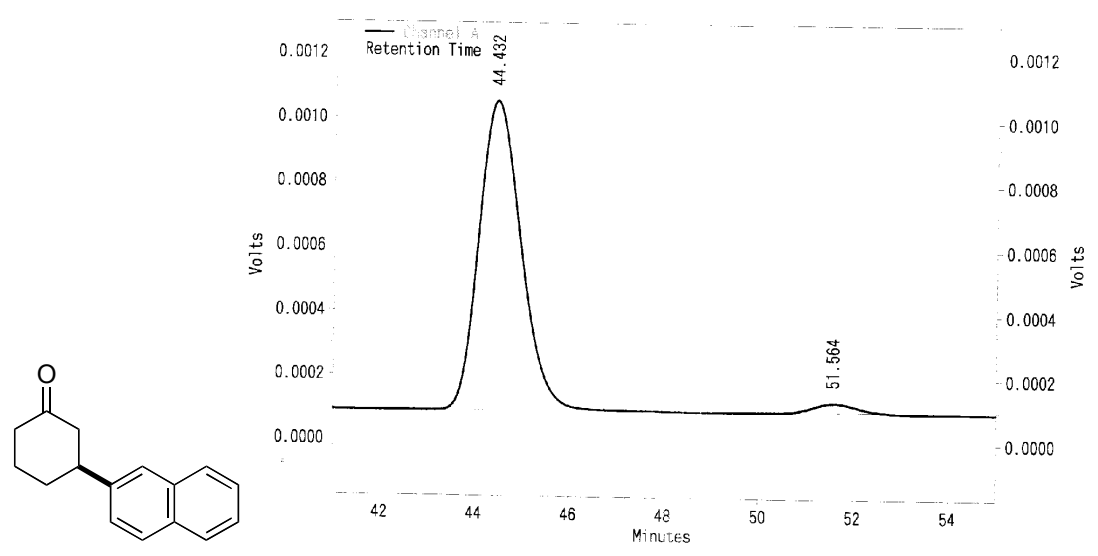

94\% ee (OD-H, hexane/2-propanol = 50/1, $0.5 \mathrm{~mL} / \mathrm{min}, 44.4$ and $51.6 \mathrm{~min}$ for major and minor). 